\title{
Freeze-Thaw Deicing salt Attack on Concrete: Towards Engineering Modelling
}

\author{
Charlotte Thiel, Vadym Lomakovych and Christoph Gehlen \\ Centre for Building Materials, Technical University of Munich, Franz-Langinger-Str. 10, 81245 \\ Muenchen, Germany, charlotte.thiel@tum.de
}

\begin{abstract}
In order to reduce carbon dioxide emissions, the construction sector is increasingly using clinker-reduced concretes. Concrete with high amounts of ground granulated blast furnace slag (GGBFS) show increased durability performance in certain environmental conditions compared to concrete with Ordinary Portland cement (OPC). However, in laboratory studies, concrete with GGBFS show an increased initial scaling rate in comparison with OPC concrete. Changing weather conditions and high relative humidities $>70 \%$ in field lead to less carbonation and thus, to a better freeze-thaw deicing salt resistance (FTDSR). Therefore, the current lab performance test penalizes GGBFS concrete. This contribution studied the impact of carbonation and intermittent dry periods on FTDSR of GGBFS concrete compared to that of OPC concrete. It could be shown that for concrete with OPC, intermittent dry periods lead to an accumulation of salt in the near surface, which causes a reduction of the scaling. GGBFS concrete, on the other hand, shows an opposite behavior: carbonation causes an increase in scaling after the dry period. GGBFS concrete samples with $\mathrm{CO}_{2}$-free pre-storage show the lowest scaling of all samples investigated. A better simulation of the behavior of GGBFS concrete could lead to economical as well as optimized solutions for the local environment conditions and enable the large-scale use of more environmentally-friendly concretes. Therefore, by taking the effect of carbonation and intermittent dry periods into account in a simple engineering model, the prediction of concrete scaling under consideration of real climatic conditions is possible in an eco-efficient manner.
\end{abstract}

Keywords: Freeze-Thaw Deicing Salt Attack, Carbonation, Durability, Service Life Prediction, Combined Attack.

\section{Introduction}

With the increased use of clinker-reduced concretes, the evaluation of durability design methods remains a topical issue. There are mainly three design strategies:

- Deemed to satisfy rules: Avoidance of damage by complying with the requirements from the exposure classes, and

- Lab-Performance concept: Compliance tests with accepted limit criteria provide a yes/no decision on the suitability of a material for a certain environment; see (Thiel and Gehlen, 2018).

- Performance based durability design: The condition of a structure remains with a certain reliability below selected limit states (Gehlen, Schieß1 and Schieß1-Pecka, 2008.; fib, 2006).

Performance based durability design can be further divided into fully probabilistic approaches, and the partial safety approach derived from the probabilistic concept. Probabilistic service life design require deterioration-time-laws that account for statistical uncertainty. An important input parameter is the material resistance, which is usually determined in compliance tests in the laboratory, (Thiel and Gehlen, 2018). Those engineering models should be as simple as possible in order to promote acceptance. In addition, different attack intensities, i.e. different 
climatic conditions should be realistically displayed. They should also be flexible so that new materials, new knowledge or new situations (e.g. climate change) can be accounted for. The use of performance based design concepts offer the following advantages

- Quantification of deviations between execution and planning

- Optimized maintenance strategies through service life prediction

- Optimized choice of material as well as curing time and type

- Simplified use of new building materials through proof of performance

Djuric successfully combined the critical saturation model from Fagerlund (Fagerlund, 2004) with the transport mechanism of the micro ice lens pump (Setzer, 1999) for pure freezethaw attack, thus developing a model for the evolution of internal structural damage (Djuric, 2017). For the durability assessment of structural components under combined freeze-thaw deicing salt attack (FTDSA), different approaches exist. For example, a simple performance concept based on the CDF method was proposed by Guse (Guse, 2009). The glue-spall model developed by Valenza (Valenza and Scherer, 2007) is able to explain most observations during FTDSA. An easy and structured factor approach was proposed by Sarja et al. (Sarja and Vesikari, 1996) and further developed by Lowke et al. (Lowke and Brandes, 2008). Currently, Müller et al. (Mueller; Ludwig and Erhardt, 2019) are combining the cryogenic suction model with frost suction in order to model the scaling evolution under FTDSA.

However, evidence of large-scale practical applications of these concepts is still missing. The aim of this contribution is to demonstrate, by means of practical experiments, how the strongly varying attack intensity under field conditions can be taken into account.

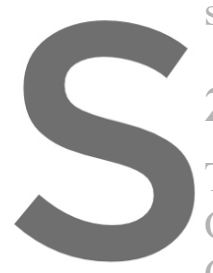

2 Materials and

Two concrete mixes

Ordinary Portland

CEM III/B $42.5 \mathrm{~N}$ contained
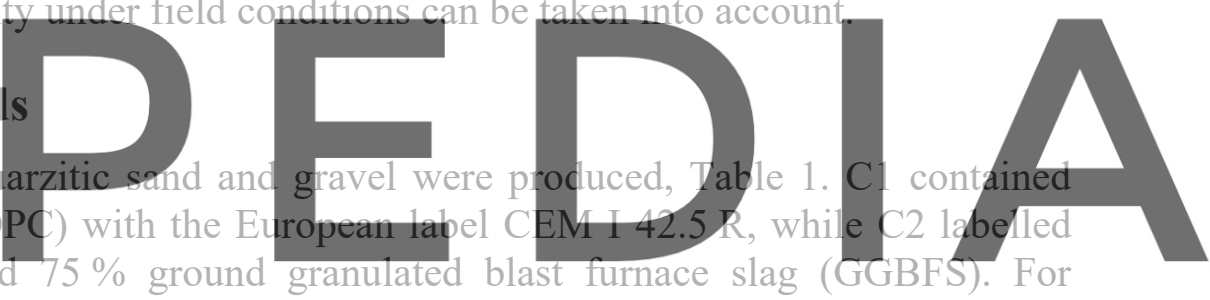

carbonation to occur, a rather high w/b-ratio of 0.55 was used. Therefore, the concrete

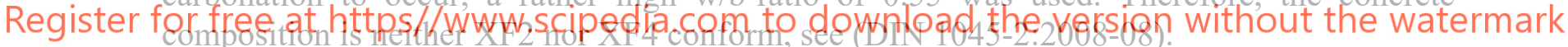

Table 1. Concrete composition, air content and compressive strength.

\begin{tabular}{ccc}
\hline & $\mathrm{C} 1$ & $\mathrm{C} 2$ \\
\hline Binder type & OPC & GGBFSC \\
\hline Binder amount $\left(\mathrm{kg} / \mathrm{m}^{3}\right)$ & 320 & 320 \\
\hline $\mathrm{w} / \mathrm{b}-$ ratio & 0.55 & 0.55 \\
\hline Sand + Gravel $\left(\mathrm{kg} / \mathrm{m}^{3}\right)$ & 1732 & 1724 \\
\hline Air content & 1.9 & 2.0 \\
\hline 28d compressive strength & 42.5 & 38.5 \\
\hline
\end{tabular}

Entrained air is the dominant factor in ensuring high FTDSR for OPC based systems (Powers, 1949). However, Auberg showed that the FTDSR of concrete with GGBFS $\geq 58 \%$ in the cement was largely unaffected by entrained air voids (Auberg, 1999). Furthermore, entrained air is not required in the exposure class XF2. As this contribution intends to exploit the potential of non-entrained concrete more effectively, no air-entraining agent was used. Carbonation leads to increased initial scaling and is the dominant parameter for concrete with 
GGBFS cement. Ludwig justified this observation with the coarsening of the pore structure due to the formation of metastable aragonite and vaterite, which are dissolved by FTDSA. 25 cubes (edge length $150 \mathrm{~mm}$ ) were cast against PTFE slides, immediately covered with moist cloth and stored at $20 \pm 2{ }^{\circ} \mathrm{C}$. After demoulding at an age of $1 \mathrm{~d}$, the samples were stored further $6 \mathrm{~d}$ under water. Then the samples were cut according to the CDF method (DIN CEN-TS 123909:2017-05) and divided in five different series of five samples each, Fig. 1.

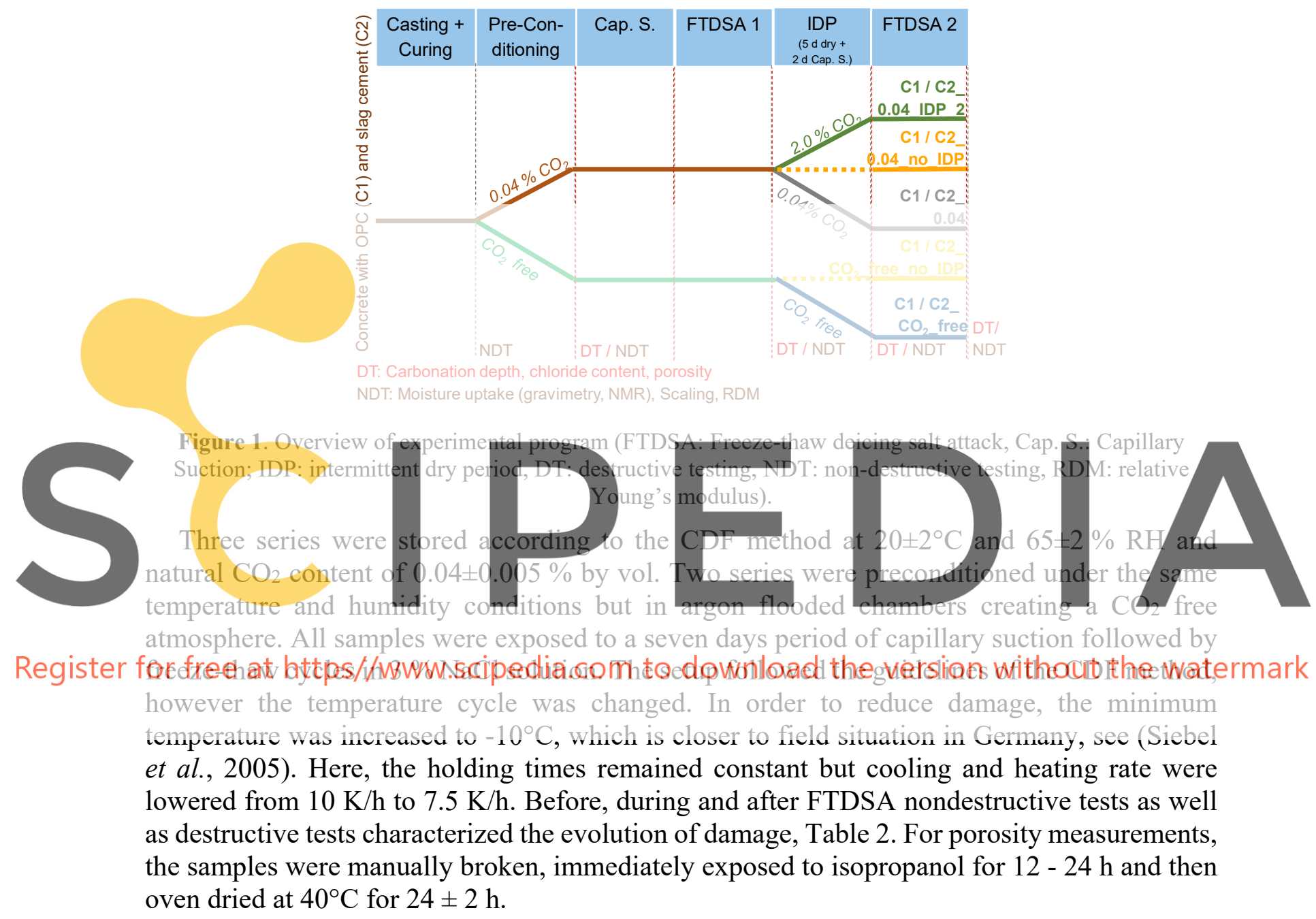


Table 2. Experimental methods.

\begin{tabular}{|c|c|c|c|}
\hline Test & Goal & Device & Reference \\
\hline $\begin{array}{c}\text { Modified CDF }\left(-10^{\circ} \mathrm{C}\right): \\
\text { Scaling, Relative } \\
\text { Young's Modulus } \\
\text { (RDM), solution uptake }\end{array}$ & $\begin{array}{l}\text { Determination of } \\
\text { scaling rate and } \\
\text { possible relation to } \\
\text { moisture uptake }\end{array}$ & $\begin{array}{l}\text { Chamber, Balance, } \\
\text { US-equipment } \\
\text { (Pundit) }\end{array}$ & $\begin{array}{c}\text { (DIN CEN-TS } \\
12390-9: 2017-05)\end{array}$ \\
\hline $\begin{array}{c}\text { Carbonation depth } \\
\text { (colour indicator spray } \\
\text { test) }\end{array}$ & $\begin{array}{l}\text { Determination of the } \\
\text { effect of carbonation }\end{array}$ & $\begin{array}{c}\text { Spray bottle with } 1 \% \\
\text { phenolphthalein in } \\
70 \% \text { ethanol }\end{array}$ & $\begin{array}{c}\text { (RILEM CPC-18, } \\
1988)\end{array}$ \\
\hline $\begin{array}{l}\text { Mercury Intrusion } \\
\text { Porosimetry (MIP) }\end{array}$ & $\begin{array}{l}\text { Determination the } \\
\text { effect of carbonation } \\
\text { and FTDSA on pore } \\
\text { structure }\end{array}$ & $\begin{array}{l}\text { AutoPore III, hammer } \\
\text { for crushing }\end{array}$ & $\begin{array}{l}\text { (Lomakovych, } \\
\text { V., 2018) }\end{array}$ \\
\hline
\end{tabular}

\section{Results and Discussion}

Fig. 2 shows scaling, moisture uptake and RDM of the concretes. Especially the accelerated carbonation leads to a five times higher scaling rate for $\mathrm{C} 2$. The orange line (C1/2_0.04_no_IDP) represents the standardized procedure (DIN CEN-TS 12390-9:2017-05), which is quite in the middle of the different series. Despite the significant effect of the different storage conditions, the carbonation depth in general was very low. Thus, Table 3 shows only the carbonation depth of the series with which a color chan
samples, for example, only the surface was usuality uncolored,
the $\mathrm{C} 2$ was $0.1 \mathrm{~mm}$, which disappeared in the course of the 14
carbonation was detected before the intermittent dry period (ID
layer scaled off.

Table 3. Carbonation depth (mm).
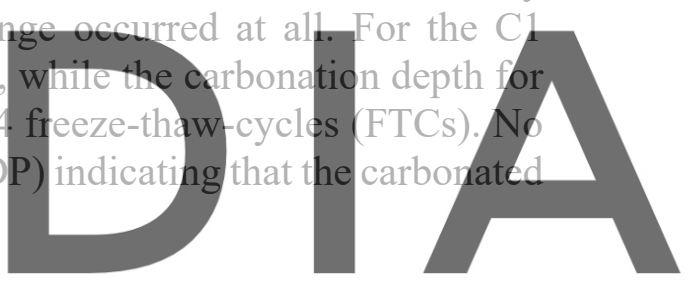

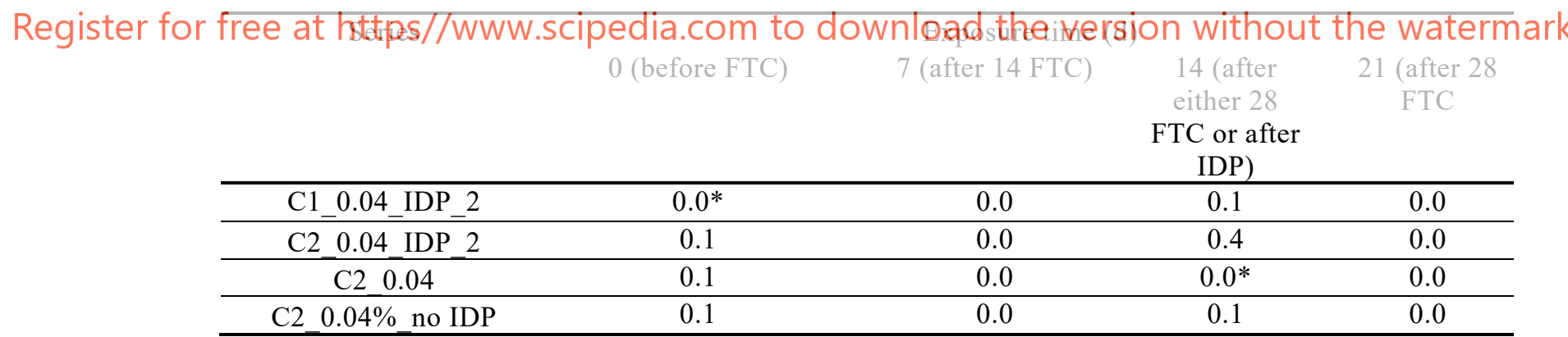

*Surface was colorless (carbonation depth $<0.1 \mathrm{~mm}$ )

The solution uptake shown in Fig. 2 middle correlates neither with the external damage nor with the drop of the RDM (bottom). After an IDP, the samples very quickly reabsorb moisture; however, for all series the total solution uptake remains below the level of the continuously exposed series. The RDM of the $\mathrm{C} 1$ only decreases for samples that have not been dried in the meantime ("no_IDP"). The high scatter of the reference series (C1/2_0.04_no_IDP) is most likely due to detaching of the sealing of two samples. This is also reflected in the RDM.

$\mathrm{C} 2$ did not show any significant changes in RDM. This could be due to the finer pore structure, 
Fig. 3. C1 has a lower total porosity before and after the FTDSA compared to C2.
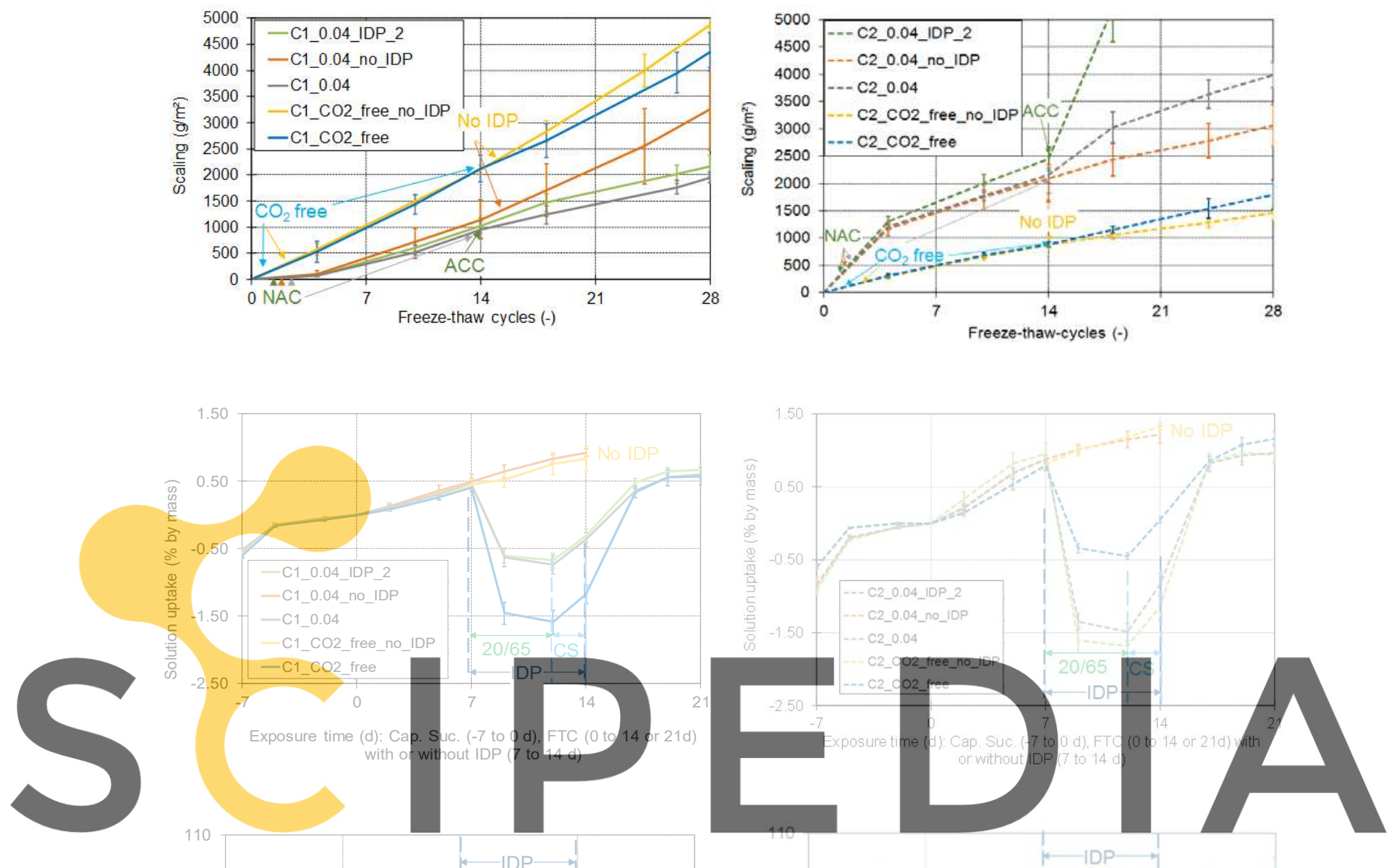

Register for free at https//Www.scipedia.com to download the version without the watermark
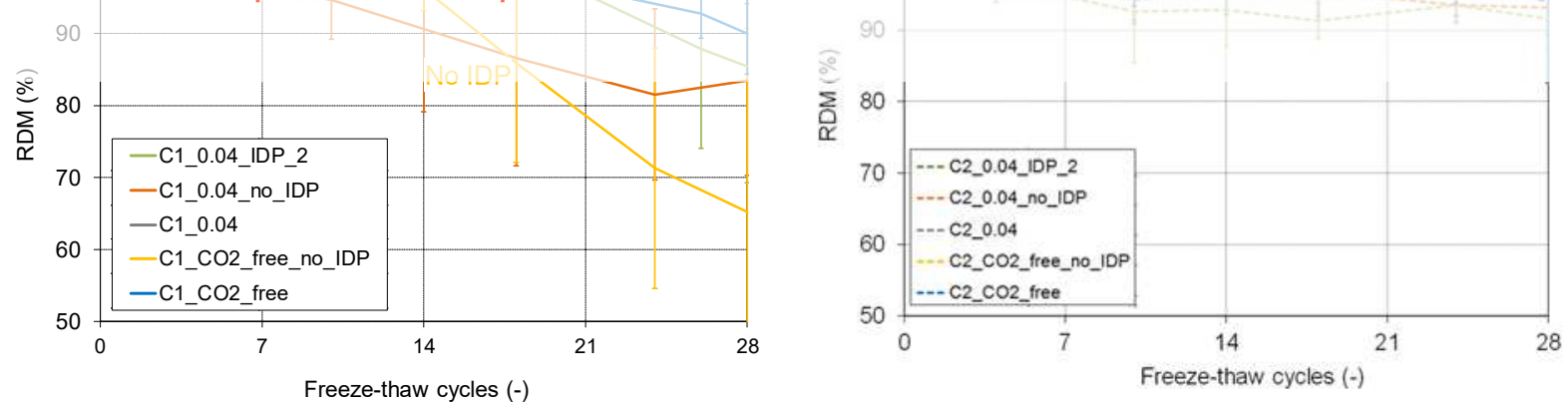

Figure 2. Top: Scaling of C1 (left) and C2 (right), middle: solution uptake of C1 (left) and C2 (right) (note: $\mathrm{x}-$ axis starts with dry state before capillary suction and represents the exposure time); bottom: Relative Young's modulus of C1 (left) and C2 (right). (NAC: Natural Carbonation; ACC: Accelerated Carbonation, CS: Capillary suction).

In all cases, FTDSA led to an increased total porosity. Note that only concrete exposed to three weeks of natural carbonation was measured as "before FTDSA". The carbonation front was already scaled off which explains why the well described coarsening of the pore structure 
due to carbonation in $\mathrm{C} 2$ was not found here. C1_0.04_no_IDP had the highest total porosity and a clear increase in the capillary pore range. This clearly indicates micro-cracking which is also confirmed by the RDM (Fig. 2 middle left). While a coarsening of the pore structure occurred for $\mathrm{C} 1$, the pore structure became finer in all $\mathrm{C} 2$ series, Fig. 3. This is most likely due to ongoing hydration. To simplify matters, if the carbonated surface layer is scaled off, GGBFS concrete show higher FTDSR than OPC concretes with otherwise identical composition. However, IDPs can cause the exposed surface layer to carbonate again, resulting in high initial scaling, corresponding to the carbonation depth. With OPC the behaviour is reversed. This shows that a test according to $28 \mathrm{~d}$ is not sufficient to describe the damage behaviour in practice and that it is absolutely necessary to consider the age and the degree of carbonation and hydration.

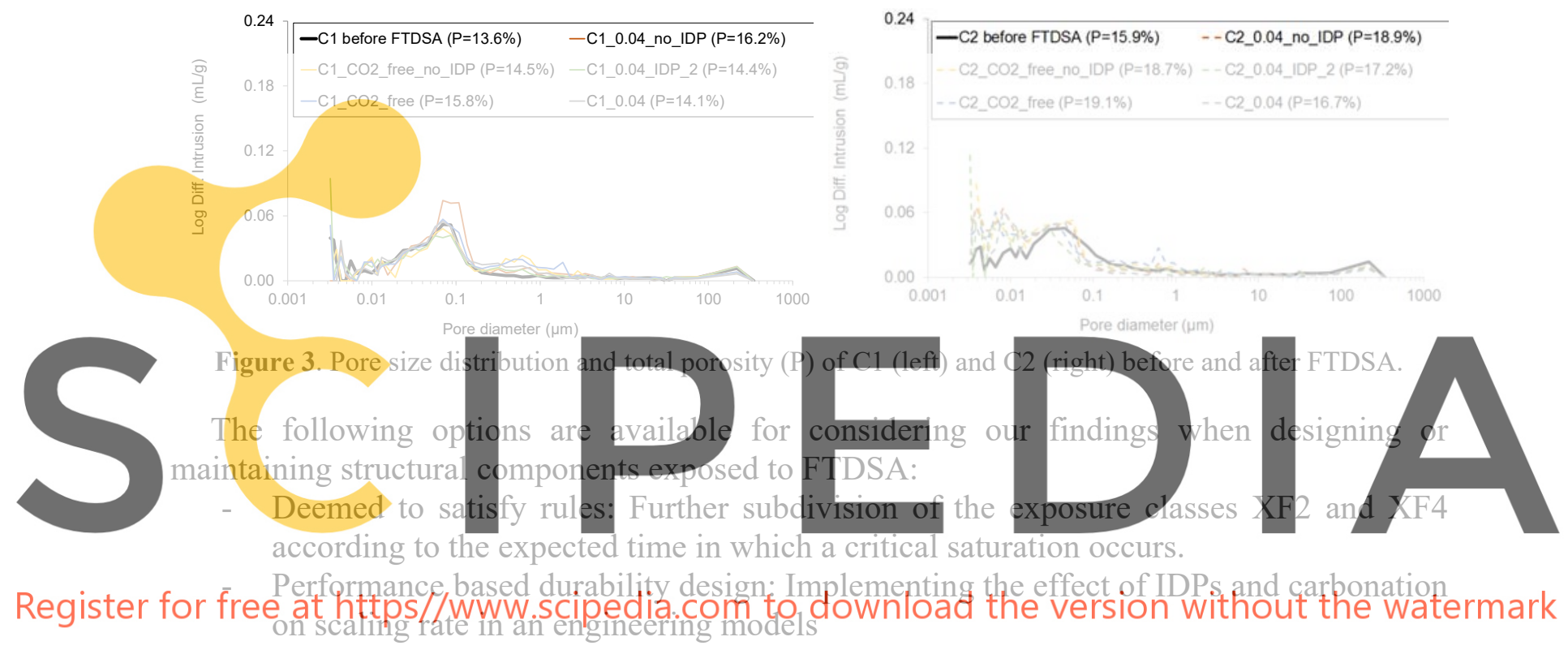

\section{Engineering IMTodel}

For chloride-induced corrosion as well as for carbonation validated probabilistic models exist (Gehlen, 2000). For carbonation induced corrosion, the effect of changing moisture conditions is taken into account by a parameter for considering the effect of micro-climatic conditions (relative humidity) and a parameter for considering the macro-climatic conditions (time of wetness and probability of wind-driven rain for vertical components. A similar procedure could be used for scaling due to FTDSA: The scaling rate over time $s_{r}(t)$ can be described by including the initial scaling rate and a later scaling rate determined in a lab performance test. The initial scaling rate $s_{r, i n i}$ accounts for the effect of carbonation while the later scaling rate $s_{r, p r o g}$ represents the evolution of scaling of the uncarbonated material under damage-relevant environment. The environment only leads to scaling when sufficient moisture, rather low chloride content and a minimum Temperature below $-5^{\circ} \mathrm{C}$ are present at the same time. This is included in the environment factor $f_{e}$, which depends on the number of damage-relevant freezethaw-cycles in one winter period as well as on the outer salt concentration and the minimum 
temperature. As the resistance of the concrete is affected by curing, the curing factor $f_{c}$ is also introduced, Equation 1.

$$
s_{r}(t)=\left(s_{r, \text { ini }}+t \cdot s_{r, p r o g}\right) \cdot f_{c} \cdot f_{e} \cdot f_{a}
$$

This approach allows a weighting of the different scaling rates. The exact statistical distributions as well as dependencies need to be quantified in future. Moreover, suitable limit states need to be defined. Scaling not only leads to visual defects, it also reduces the concrete cover. Cracking reduces mechanical performance and might accelerate other mechanisms relevant to durability. Therefore, a much lower scaling depth than the concrete cover is certainly tolerable.

\section{Conclusions and Outlook}

FTDSA is very versatile. It strongly depends not only on the material resistance but also on the macro- and micro-climatic conditions. Recent investigations (Aßbrock et al., 2019) showed that for most European locations, freeze-thaw deicing salt attack (FTDSA) is milder than displayed in laboratory tests. Consequently, there is a need for eco-efficient and economic methods to design and maintain structures under FTDSA despite the current deemed to satisfy rules. The most important findings of this contribution are summarized as follows:

Damage evolution strongly depends on the climatic conditions. The scaling rate can

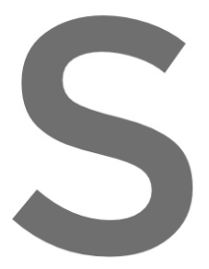
change conside without precipitation. For concrete and without probably salt cry
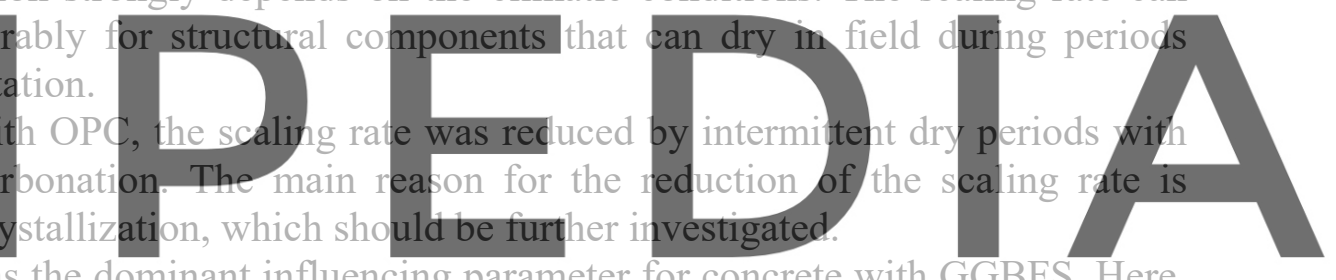

Carbonation was the dominant influencing parameter for concrete with GGBFS. Here,

Register for free after at IDP/ concrete with GGBES will always exhihit a new increased initiat scaling

for concrete with OPC. Concretes with high amount of GGBFS could be used in building components that are exposed to low carbonation (few dry periods, high relative humidity).

- Palecki (Palecki, 2005) and others found a correlation between inner damage and moisture uptake for freeze-thaw attack without deicing agents. This correlation could not be confirmed for FTDSA. Although concrete with GGBFS absorbed more solution than concrete with OPC, the finer pore structure caused only minor changes in the RDM while concrete with OPC showed a significant drop in RDM.

- IDPs significantly reduce the occurrence of inner damage.

- A new concept was proposed to consider the effect of real weather data and include the effect of carbonation. With the help of this, a weighting of the different scaling rates of the carbonated and non-carbonated layers would be possible.

- Taking into account the actual performance of the material as well as the actual expected intensity of attack would enable more economic and eco-efficient design of concrete structures. 


\section{ORCID}

Charlotte Thiel: https://orcid.org/0000-0002-0092-468X

Vadym Lomakovych: -

Christoph Gehlen: https://orcid.org/0000-0002-1214-3960

\section{References}

Aßbrock, O. et al. (2019). Schlussbericht zum AiF-Forschungsvorhaben 15214 BG „Verbundforschung Frost- und FrostTausalz-Widerstand von Beton unter besonderer Berücksichtigung der verwendeten Gesteinskörnungen“. https://www.transportbeton.org/fileadmin/transportbeton-org/media/Branche/pdf/2019-05-21-Frostwiderstand_ Gesteinskoernung_im_Beton_Schlussbericht_gesamt_15214_BG_online.pdf, downloaded on 11/20/2019.

Auberg R. (1999). Zuverlässige Prüfung des Frost-und Frost-Tausalz-Widerstands von Beton mit dem CDF-und CIF-Test. Doctoral thesis. Universität Essen. Shaker Verlag.

DIN 1045-2:2008-08 Concrete, reinforced and prestressed concrete structures - Part 2: Concrete - Specification, properties, production and conformity - Application rules for DIN EN 206-1. Beuth. dx.doi.org/10.31030/1453177

DIN CEN-TS 12390-9:2017-05. Testing hardened concrete - Part 9: Freeze-thaw resistance with de-icing salts - Scaling; German version CEN/TS 12390-9:2016. Beuth. dx.doi.org/10.31030/2649732

Đuric, Z. (2017). Sättigungsverhalten und Schädigung von Zementstein bei Frostbeanspruchung. KIT Karlsruhe. Institut für Massivbau und Baustofftechnologie (IMB). DOI: 10.5445/IR/1000079299

Fagerlund, G. (2004). A Service Life Model for International Frost Damage in concrete. TVBM-3119, Lund, Institute of Technology, Division of Building Materials

Gehlen, C. (2000). Probabilistische Lebensdauerbemessung von Stahlbetonbauwerken : Zuverlässigkeitsbetrachtungen zur wirksamen Vermeidung von Bewehrungskorrosion. Doctoral thesis. Aachen, Technische Hochschule.

Gehlen, C., Schießl, P. and Schießl-Pecka, A. (2008). Hintergrundinformationen zum Positionspapier des DAfStb zur Umsetzung des Konzepts von leistungsbezogenen Entwurfsverfahren unter Berücksichtigung von DIN EN 206-1, Anhang J, für dauerhaftigkeitsrelevante Problemstellungen. Beton- und Stahlbetonbau, 840 -851. doi.org/10.1002/best.200808230

Guse. U. (2009). Frost- und Frost-Taussalz-Prifverfahren Grundlagen, Planung Universitätsverlag Karls

fib (International Federation code Bulletin 34

Lomakovych, V. (2018). Ein flu Tausalz-Beanspruchung. Te
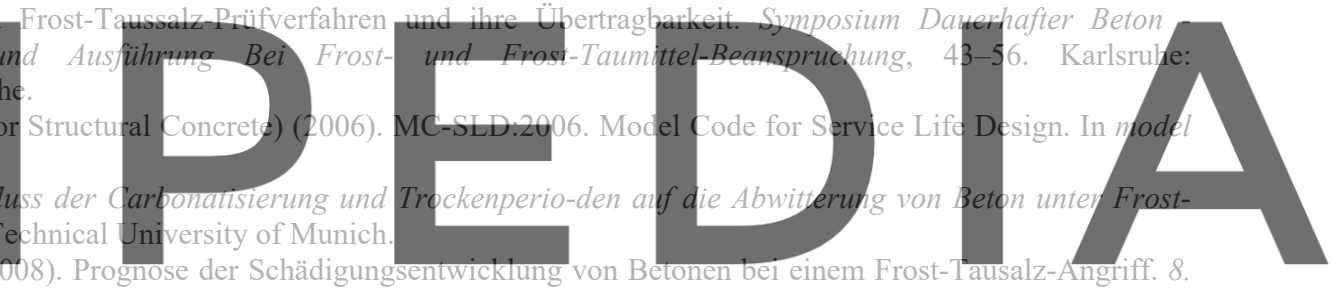

Lowke, D, and Brandes, Münchner Baustoffseminar, cbm TU München.

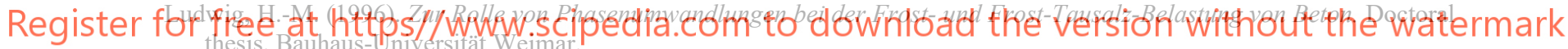

Müller, M.; Ludwig, H.-M. and Ehrhardt, D. (2019). Frost-Tausalz-Angriff auf Beton: Mechanismen und Schadensmodelle. Beton- und Stahlbetonbau 114(1). https://doi.org/10.1002/best.201800096

Palecki, S. (2005). Hochleistungsbeton unter Frost-Tau-Wechselbelastung : Schädigungs- und Transportmechanismen. Doctoral thesis. Universität Duisburg-Essen.

Powers, T. C. (1949). The air requirements of frost-resistantconcrete. Proceedings of the Twenty-Ninth Annual Meeting of the Highway Research Board Held at Washington, D.C.

RILEM CPC-18 (1988). Measurements of hardened concrete carbonation depth. Materials and Structures, 21, 453-455.

Sarja, A. and Vesikari, E. (1996). Durability Design of Concrete Structures, Rilem Report 14, Taylor and Francis,

London and New York.

Setzer, M.J. (1999). Mikroeislinsenbildung und Frostschaden. Werkstoffe im Bauwesen - Theorie und Praxis. Eligehausen (edts), Ibidem Verlag, Stuttgart. 394-413.

Siebel et al. (2005). Sachstandbericht Übertragbarkeit von Frost-Laborprüfungen auf Praxisverhältnisse. Heft 560 der Schriftenreihe des Deutschen Ausschuss für Stahlbeton. Beuth. Berlin. 2005. ISBN 3-410-65760-6.

Thiel, C. and Gehlen, C. (2018). Compliance testing for probabilistic durability design purposes. Proceedings of The 6th International Symposium on Life-Cycle Civil Engineering (IALCCE), Ghent, Belgium.

Valenza, J.J., Scherer, G.W. (2007). A Review of Salt Scaling: II. Mechanisms. Cement and Concrete Research, 37, 10221034. doi.org/10.1016/j.cemconres.2007.03.003. 